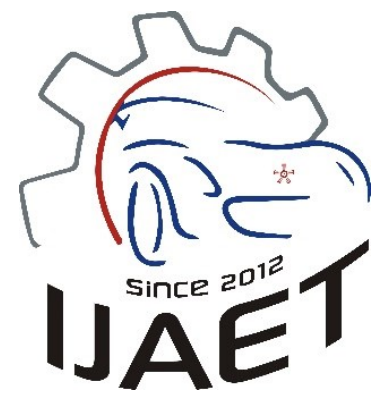

e-ISSN: 2146 - 9067

International Journal of Automotive

Engineering and Technologies

journal homepage: http://ijaet.academicpaper.org

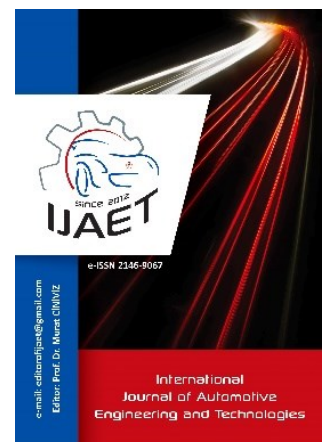

Original Research Article

\title{
Investigation of Fuel Properties of Canola Oil Biodiesel, Bioethanol and Diesel Fuel Mixture
}

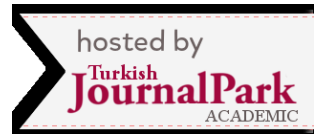

\author{
Tuğba Şahin ${ }^{1}$, Fatih Aydın ${ }^{2 *}$ \\ ${ }^{1}$ Altuntaş Grup Aemot Electric Motors, Aksaray / Turkey \\ ${ }^{2}$ Necmettin Erbakan University, Ereğli Faculty of Engineering and Natural Sciences, 42310 Konya / Turkey
}

\section{ARTICLE INFO \\ * Corresponding author \\ fatihaydin@konya.edu.tr \\ Received: November 01, \\ 2018 \\ Accepted: November 18, \\ 2018}

Published by Editorial Board Members of IJAET

(C) This article is distributed by Turk Journal Park System under the CC 4.0 terms and conditions.

\begin{abstract}
In this study, canola oil was converted into Canola Oil Methyl Esters (Canola Biodiesel) by transesterification method and biodiesel production was carried out. Biodiesel fuel obtained from canola oil was mixed with diesel fuel with $5 \%$ and $10 \%$ bioethanol addition and by inversion with volumetric proportions, and then fuels in the form of $\mathrm{D}_{100}, \mathrm{~B}_{100}, \mathrm{E}_{5} \mathrm{~B}_{5} \mathrm{D}_{90}, \mathrm{E}_{10} \mathrm{~B}_{10} \mathrm{D}_{80}, \mathrm{E}_{10} \mathrm{~B}_{5} \mathrm{D}_{85}$ and $\mathrm{E}_{5} \mathrm{~B}_{10} \mathrm{D}_{85}$ were obtained.

Fuel properties of the obtained mixtures and diesel fuel, density, water content, kinematic viscosity, $\mathrm{pH}$ value, flash point, color specification, calorific value, clouding, pour and freezing point tests, CFPP (Cold Filter Plugging Point) test and copper rod corrosion tests were performed.

According to the test results, it was concluded that biodiesel produced from canola oil could be used as $100 \%$ in diesel engines blending with bioethanol and without any modification on the engine; and it was an alternative fuel to diesel fuel.

Keywords: Canola, bioethanol, biodiesel.
\end{abstract}

\section{Introduction}

Today, around $20 \%$ of the energy consumed worldwide is derived from renewable sources. Although the dependence on fossil fuels is currently high, the rates of renewable energy usage are increasing gradually over the years [1].

However, despite all attempts, renewable energy sources are still facing high obstacles in the energy markets. There are many reasons for this. The most notable one is that renewable energy sources are regarded as economically weak compared to fossil fuels. This depends more on traditional price configuration. Because, in this price configuration, there are no social and environmental costs, provision and usage costs. Moreover, there are many institutional and financial obstacles in establishing even a small size renewable resource [2].

There are important supports for alternative fuel researches around the world. In many developed countries, especially in European Union countries, serious studies are carried out on this subject and positive results are put into practice. The alternative fuel that can be used in 
diesel engines must have economic, renewable, environmental friendly and easily available advantages. Biodiesel is considered as an alternative fuel type for diesel engines with features that meet these requirements [3].

Biodiesel is defined as fatty acid methyl esters according to current standards. In parallel with the developments and the targets in the world of biofuels, it is envisaged that fatty acid ethyl esters will become increasingly important and flexible fuel vehicle applications will also be used in practice $[4,5]$.

Although there are various methods of biodiesel production, the most widely used method today is transesterification. In the transesterification method; biodiesel is an environmentally friendly and renewable liquid biofuel which is released with a short chain alcohol (usually methanol or ethanol) by means of a catalyst and as a result of transesterification reaction of the oils or animal oils obtained from oilseed plant such as rapeseed (canola), sunflower, and soybean [6].

Although fuel alcohol is a definition including methyl alcohol and ethyl alcohol, it is commonly used for ethyl alcohol (ethanol bioethanol) derived from biomass sources [7].

Bioethanol is simply a colorless, clear, flammable, oxygenated hydrocarbon. Bioethanol is a fuel that can be obtained from various sources. Cereals, seeds, sugar products and other starch sources can be easily fermented to produce bioethanol. The use of bioethanol as fuel in the world is mostly in the form of low mixing ratios [8].

Today, the biofuel industry has become one of the most important business areas. Bioethanol and biodiesel, one of the first generation biofuels among the biofuels classified as four generations according to the type of production, raw material selection and technologies, are in intensive practice and bioethanol is the leading biofuel in the world $[4,9]$.

\section{Materials and Methods}

Canola oil used in this study was obtained from the market. The biodiesel of this oil was produced in the laboratory of the Department of Energy Systems Engineering at Necmettin Erbakan University Faculty of Engineering and Architecture. Transesterification method was used as the production method, $\mathrm{NaOH}$ was used as the catalyst and methyl alcohol as alcohol. Diesel fuel was supplied from BP Petrol Company.

Biodiesel fuel obtained from canola oil was mixed with diesel fuel with $5 \%$ and $10 \%$ bioethanol addition and by inversion with volumetric proportions, and then fuels in the form of $\mathrm{D}_{100}, \quad \mathrm{~B}_{100}, \quad \mathrm{E}_{5} \mathrm{~B}_{5} \mathrm{D}_{90}, \quad \mathrm{E}_{10} \mathrm{~B}_{10} \mathrm{D}_{80}$, $\mathrm{E}_{10} \mathrm{~B}_{5} \mathrm{D}_{85}$ and $\mathrm{E}_{5} \mathrm{~B}_{10} \mathrm{D}_{85}$ were obtained. Fuel properties of the obtained mixtures and diesel fuel, water content, color specification, calorific value, flash point, copper rod corrosion tests, CFPP tests were performed at Biodiesel Laboratory of the Department of Agricultural Machinery and Technologies Engineering at Selçuk University, Faculty of Agriculture; kinematic viscosity, density, $\mathrm{pH}$, clouding, pour and freezing point tests were performed at the Department of Energy Systems Engineering at Necmettin Erbakan University Faculty of Engineering and Architecture. Test fuels were defined in Table 1.

Test results were defined in Table 2. It is seen that the values in the table comply with TS EN 590 for diesel and TS EN 14214 for biodiesel. Properties of test devices were defined in Table 3.

Table 1. Names of the test fuels [10]

\begin{tabular}{cccc}
\hline Fuels & Diesel & Bioethanol & $\begin{array}{c}\text { Canola Oil } \\
\text { Biodiesel }\end{array}$ \\
\hline $\mathrm{D}_{100}$ & 100 & 0 & 0 \\
$\mathrm{~B}_{100}$ & 0 & 0 & 100 \\
$\mathrm{E}_{5} \mathrm{~B}_{5} \mathrm{D}_{90}$ & 90 & 5 & 5 \\
$\mathrm{E}_{10} \mathrm{~B}_{10} \mathrm{D}_{80}$ & 80 & 10 & 10 \\
$\mathrm{E}_{10} \mathrm{~B}_{5} \mathrm{D}_{85}$ & 85 & 10 & 5 \\
$\mathrm{E}_{5} \mathrm{~B}_{10} \mathrm{D}_{85}$ & 85 & 5 & 10 \\
\hline
\end{tabular}


Table 2. Analyses results [10]

\begin{tabular}{|c|c|c|c|c|c|c|c|c|c|c|c|}
\hline \multirow{2}{*}{$\begin{array}{l}\text { Characteristic } \\
\text { Properties }\end{array}$} & \multirow{2}{*}{ Units } & \multirow{2}{*}{$\begin{array}{c}\text { Canola } \\
\text { oil }\end{array}$} & \multirow{2}{*}{$\mathrm{B}_{100}$} & \multirow{2}{*}{$D_{100}$} & \multirow{2}{*}{$\begin{array}{c}\mathrm{E}_{5} \mathrm{~B}_{5} \\
\mathrm{D}_{90} \\
\end{array}$} & \multirow{2}{*}{$\mathrm{E}_{10} \mathrm{~B}_{10} \mathrm{D}_{80}$} & \multirow{2}{*}{$\mathrm{E}_{10} \mathrm{~B}_{5} \mathrm{D}_{85}$} & \multirow{2}{*}{$\mathrm{E}_{5} \mathrm{~B}_{10} \mathrm{D}_{85}$} & \multirow{2}{*}{ Bioethanol } & \multicolumn{2}{|c|}{ Limiting Values } \\
\hline & & & & & & & & & & Diesel & Biodiesel \\
\hline $\begin{array}{l}\text { Density } \\
\left(15^{\circ} \mathrm{C}\right)\end{array}$ & $\mathrm{g} / \mathrm{cm}^{3}$ & 0,915 & 0,883 & 0,834 & 0,835 & 0,834 & 0,833 & 0,837 & 0,791 & $\begin{array}{c}0,82- \\
0,84\end{array}$ & $\begin{array}{c}0,86- \\
0,90\end{array}$ \\
\hline $\begin{array}{l}\text { Water } \\
\text { Content } \\
\text { Kinematic }\end{array}$ & $\mathrm{ppm}$ & 212,53 & 492,51 & 34,52 & 292,71 & 490,87 & 583,04 & 247,65 & 372,6 & 200 & 500 \\
\hline $\begin{array}{l}\text { Viscosity } \\
\left(40^{\circ} \mathrm{C}\right)\end{array}$ & $\mathrm{mm}^{2} / \mathrm{s}$ & 31,388 & 4,453 & 3,071 & 2,647 & 2,492 & 2,444 & 2,644 & 1,269 & $2-4,5$ & $3,5-5$ \\
\hline $\begin{array}{l}\text { Kinematic } \\
\text { Viscosity } \\
\left(100^{\circ} \mathrm{C}\right)\end{array}$ & $\mathrm{mm}^{2} / \mathrm{s}$ & 4,5127 & 2,044 & 1,417 & 1,125 & 1,211 & 1,051 & 1,125 & 0,697 & --------- & ------ \\
\hline $\mathrm{PH}$ & -------- & 4,8 & 4,9 & 4,01 & 5 & 5,03 & 5,02 & 5,01 & 6,12 & & - \\
\hline Flash Point & ${ }^{0} \mathrm{C}$ & 150 & 125 & 61 & ------ & -------- & ------- & ------ & ------ & 55 & 120 \\
\hline Color & ASTM & 0,8 & 1,0 & 1,3 & 1,3 & 1,3 & 1,3 & 1,3 & 0,5 & & - \\
\hline $\begin{array}{l}\text { Calorific } \\
\text { Value }\end{array}$ & $\mathrm{Cal} / \mathrm{gr}$ & ---- & 9585 & 10319 & 10876 & 10120 & 10752 & 10272 & 7068 & - & 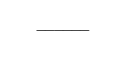 \\
\hline Cloud Point & ${ }^{0} \mathrm{C}$ & $-9,8$ & $-5,9$ & $-8,4$ & $-6,9$ & $-7,3$ & $-7,2$ & $-7,1$ & 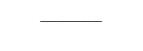 & $\longrightarrow$ & - \\
\hline Pour Point & ${ }^{0} \mathrm{C}$ & $-13,6$ & $-9,1$ & $-15,1$ & $-9,2$ & $-10,1$ & $-9,9$ & $-9,8$ & - & $\longrightarrow$ & 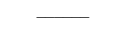 \\
\hline $\begin{array}{l}\text { Freezing } \\
\text { Point }\end{array}$ & ${ }^{0} \mathrm{C}$ & $-17,4$ & $-12,1$ & -20 & $-14,4$ & $-15,2$ & -15 & $-14,7$ & - & - & - \\
\hline CFPP & ${ }^{0} \mathrm{C}$ & -------- & -7 & -17 & -18 & -17 & -17 & -18 & $<-20$ & -20 & -15 \\
\hline $\begin{array}{l}\text { Copper Strip } \\
\text { Corrosion }\end{array}$ & ------- & $1 \mathrm{a}$ & $1 \mathrm{a}$ & $1 \mathrm{a}$ & $1 \mathrm{a}$ & $1 \mathrm{a}$ & $1 \mathrm{a}$ & $1 \mathrm{a}$ & $1 \mathrm{a}$ & No:1 & No:1 \\
\hline
\end{tabular}

Table 3. Properties of test devices

\begin{tabular}{|c|c|c|c|}
\hline Name of the Device & Trademark & Measurement Accuracy & Measuring Range \\
\hline $\begin{array}{ll}\text { Density } & \text { Measuring } \\
\text { Device } & \end{array}$ & Kem Kyoto / DA-130N & $\pm 0,0001$ & $0-40{ }^{0} \mathrm{C}$ \\
\hline $\begin{array}{l}\text { Water Content } \\
\text { Measurement Device }\end{array}$ & $\begin{array}{l}\text { Kem Kyoto Electronic } \\
\text { MKC-501 }\end{array}$ & $\pm 0,01$ & $5-35{ }^{0} \mathrm{C}$ \\
\hline $\begin{array}{l}\text { Kinematic Viscosity } \\
\text { Measuring Device }\end{array}$ & Koehler / K23377 & $\pm 0,01$ & $25-150{ }^{\circ} \mathrm{C}$ \\
\hline $\mathrm{pH}$ Meter & $\begin{array}{l}\text { Hanna Intruments / } \\
\text { HI8314 }\end{array}$ & $\pm 0,01$ & $0-14 \mathrm{pH}$ \\
\hline $\begin{array}{l}\text { Flash Point } \\
\text { Determination Device }\end{array}$ & Koehler / K16270 & $\pm 0,01$ & $0-370{ }^{0} \mathrm{C}$ \\
\hline $\begin{array}{l}\text { Automatic Color } \\
\text { Measuring Device }\end{array}$ & Lovibont / PFX195 & --------- & $0,5-8$ units \\
\hline Calorimeter Device & Ika & $\pm 0,0001$ & 0 - 40000 joule \\
\hline Chronometer & Taksun & $\pm 0,1$ & ---------- \\
\hline $\begin{array}{l}\text { Cloud, Pour and Freezing } \\
\text { Point Tester }\end{array}$ & Koehler / K46000 & $\pm 0,01$ & $(-69)-0{ }^{0} \mathrm{C}$ \\
\hline $\begin{array}{lr}\text { Cold } & \text { Filter Plugging } \\
\text { Point } & \text { Measurement } \\
\text { Device } & \end{array}$ & Tanaka / AFP-102 & $\pm 0,01$ & $(-60)-0{ }^{0} \mathrm{C}$ \\
\hline $\begin{array}{l}\text { Copper rod corrosion } \\
\text { tester }\end{array}$ & Koehler / K25330 & $\pm 0,01$ & $0-190{ }^{0} \mathrm{C}$ \\
\hline
\end{tabular}

\section{Results and Discussion}

\subsection{Density values of the fuels}

Figure 1 shows the density values of the fuels. When the test values were examined, it was seen that the density of canola oil was high, $\mathrm{B}_{100}$ and $\mathrm{D}_{100}$ fuels remained within the standards and the mixture fuels gave results close to $\mathrm{D}_{100}$ fuel. Density values were measured according to EN 61326-1 standard.

\subsection{Water content values of the fuels}

Figure 2 shows water content values of the fuels. When the test values were examined, it was seen that the water contents of the $\mathrm{B}_{100}$ and $\mathrm{D}_{100}$ fuels remained within the standards, while the canola oil and mixtures gave results close to the $\mathrm{B}_{100}$ fuel. Water content values were measured according to EN 61326-1 standard.

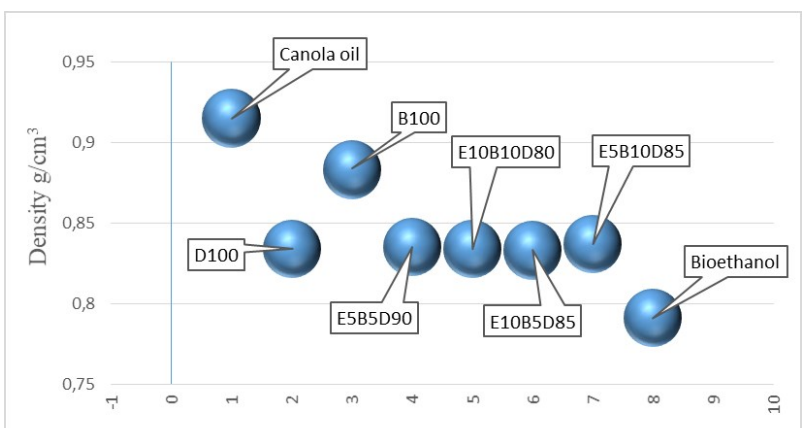

Figure 1. Density values of the fuels 


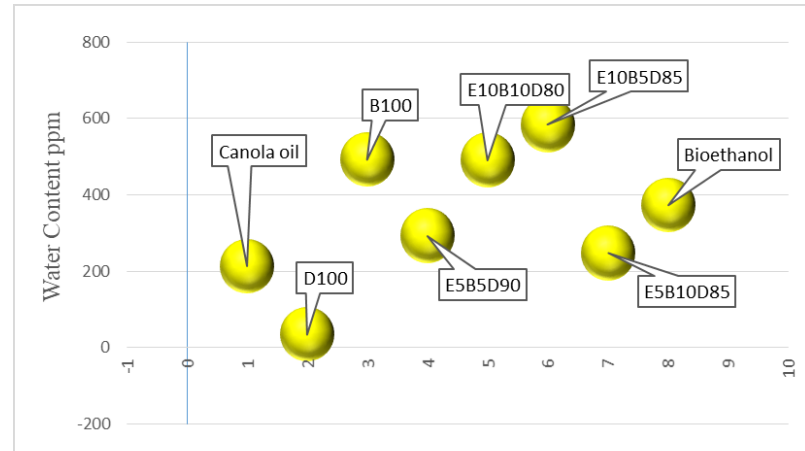

Figure 2. Water content values of the fuels

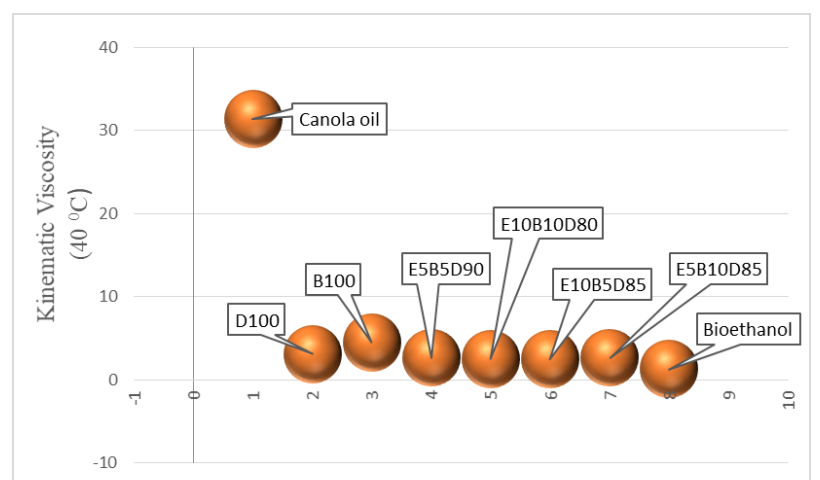

Figure 3. Kinematic viscosity values of fuels at $40^{\circ} \mathrm{C}$

\subsection{Kinematic viscosity values of fuels at $40^{\circ} \mathrm{C}$}

Figure 3 shows kinematic viscosity values of fuels at $40^{\circ} \mathrm{C}$. When the test values were examined, it was seen that canola oil had a high kinematic viscosity value at $40{ }^{\circ} \mathrm{C}$ and $\mathrm{B}_{100}$ and $\mathrm{D}_{100}$ fuels remained within the standards. The lowest viscosity value at $40{ }^{0} \mathrm{C}$ is in $\mathrm{E}_{10} \mathrm{~B}_{5} \mathrm{D}_{85}$ fuels. Kinematic viscosity values at 40 degrees Celsius were measured according to ASTM D 445 standard.

\subsection{Kinematic viscosity values of fuels at $100^{\circ} \mathrm{C}$}

Figure 4 shows kinematic viscosity values of fuels at $100^{\circ} \mathrm{C}$. When the test values were examined, it was seen that the canola oil had a high kinematic viscosity value at $100{ }^{\circ} \mathrm{C}$ and the $\mathrm{B}_{100}$ and $\mathrm{D}_{100}$ fuels remained within the standards. The lowest viscosity value at $100{ }^{\circ} \mathrm{C}$ was in $E_{10} B_{5} D_{85}$ fuels. Kinematic viscosity values at 100 degrees Celsius were measured according to ASTM D 445 standard.

\section{5. $\mathrm{pH}$ values of the fuels}

Figure 5 shows $\mathrm{pH}$ values of the fuels. When the $\mathrm{pH}$ test values were examined, the results were equivalent to each other in all fuels.

\subsection{Flash point values of the fuels}

Figure 6 shows flash point values of the fuels. When the test values were examined, it was seen that the flash point values of the fuels were in compliance with the standards. Flash point values were measured according to ASTM D 93 standard.

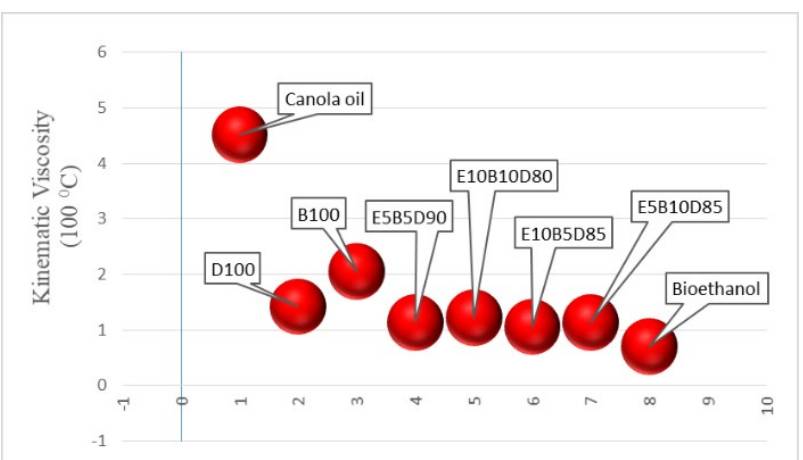

Figure 4. Kinematic viscosity values of fuels at $100^{\circ} \mathrm{C}$

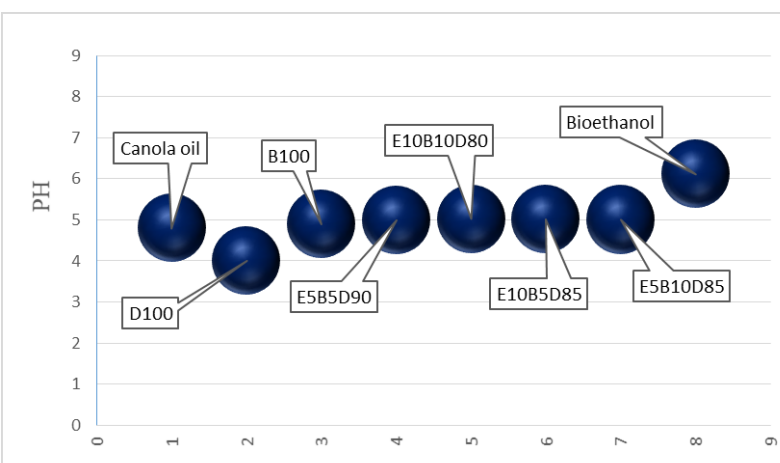

Figure 5. $\mathrm{pH}$ values of the fuels

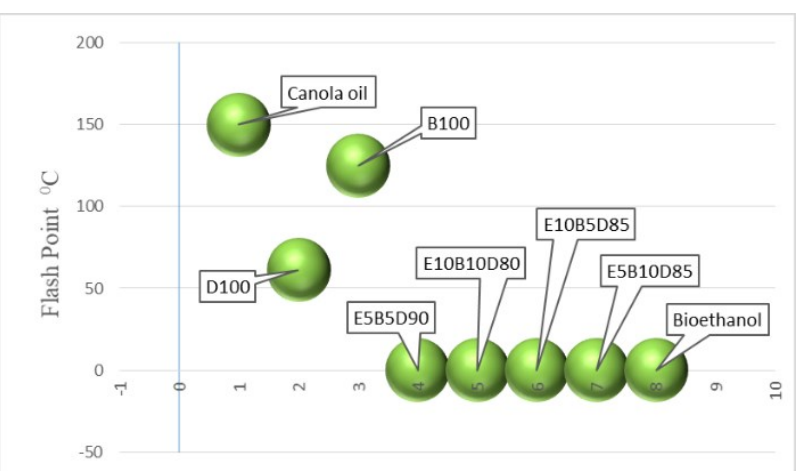

Figure 6. Flash point values of the fuels

\subsection{Color specification values of the fuels}

Figure 7 shows color specification values of the fuels. When the test values of color specification were examined, it was concluded that Canola oil and $\mathrm{B}_{100}$ fuel were lighter than other fuels. Color specification values were measured according to ASTM, CIE, Pt-Co/ Hazen / APHA color scales. 


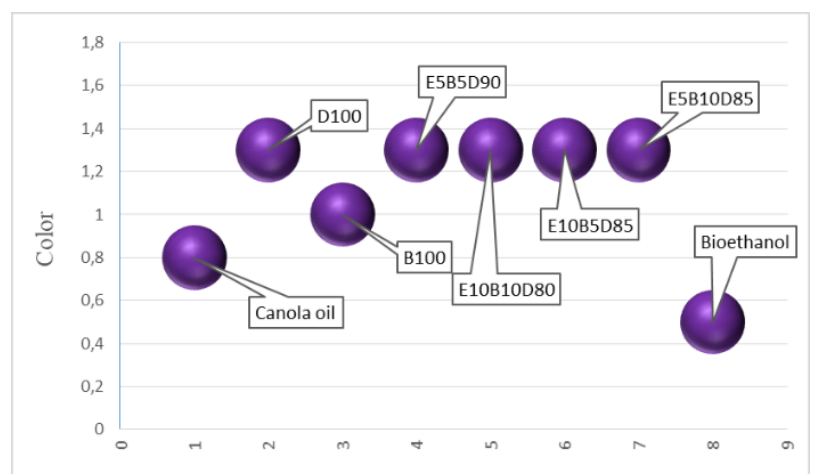

Figure 7. Color specification values of the fuels

\subsection{Calorific values of the fuels}

Figure 8 shows calorific values of the fuels. When the test values were examined, it was seen that the calorific value of $\mathrm{B}_{100}$ fuel was close to $\mathrm{D}_{100}$ fuel; and the highest calorific value was in $\mathrm{E}_{5} \mathrm{~B}_{5} \mathrm{D}_{90}$ fuel among fuel mixtures. Calorific values were measured according to EN 50082 standard.

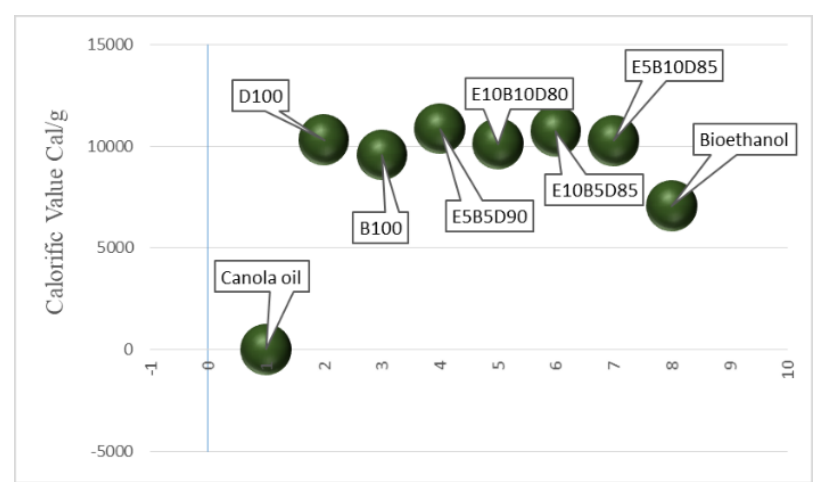

Figure 8. Calorific values of the fuels

\subsection{Cloud point values of the fuels}

Figure 9 shows cloud point values of the fuels. When the test values were investigated, it was observed that $\mathrm{D}_{100}$ fuel gave better results than the other fuels. Cloud point values were measured according to ASTM D97 standard.

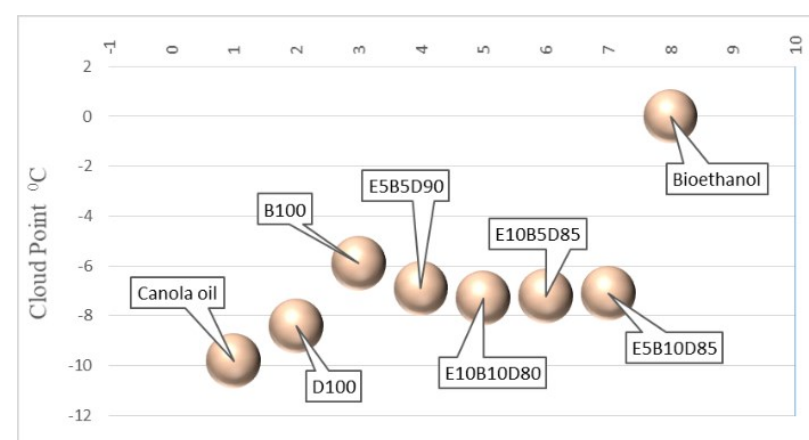

Figure 9. Cloud point values of the fuels

\subsection{Pour point values of the fuels}

Figure 10 shows the pour point values of the fuels. When the test values were investigated, it was observed that $D_{100}$ fuel gave better results than the other fuels. Pour point values were measured according to ASTM D97 standard.

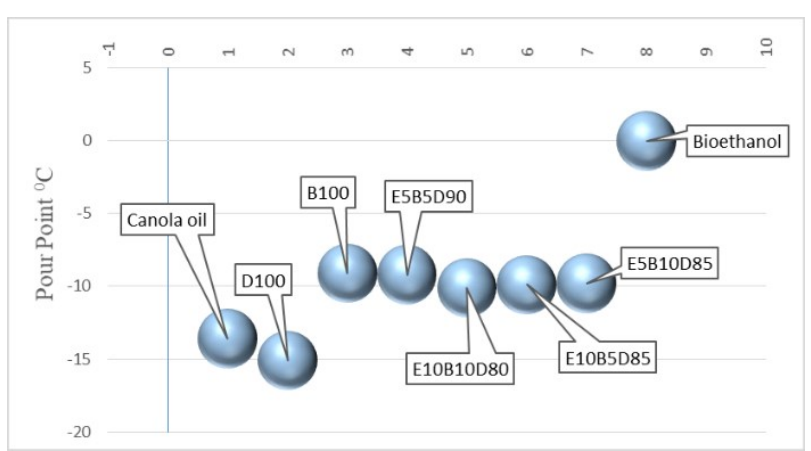

Figure 10. Pour point values of the fuels

\subsection{Freezing point values of the fuels}

Figure 11 shows freezing point values of the fuels. When the test values were investigated, it was observed that $D_{100}$ fuel gave better results than the other fuels. Freezing point values were measured according to ASTM D97 standard.

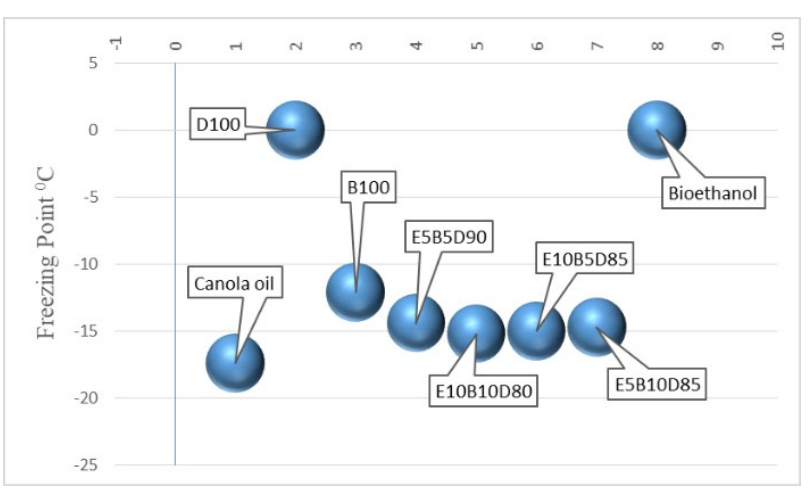

Figure 11. Freezing point values of the fuels

\subsection{Cold filter plugging point values of the fuels}

Figure 12 shows cold filter plugging point values of the fuels. When the test values were examined, it was seen that the fuels had similar results. Cold filter plugging point values were measured according to ASTM D 6371 standard.

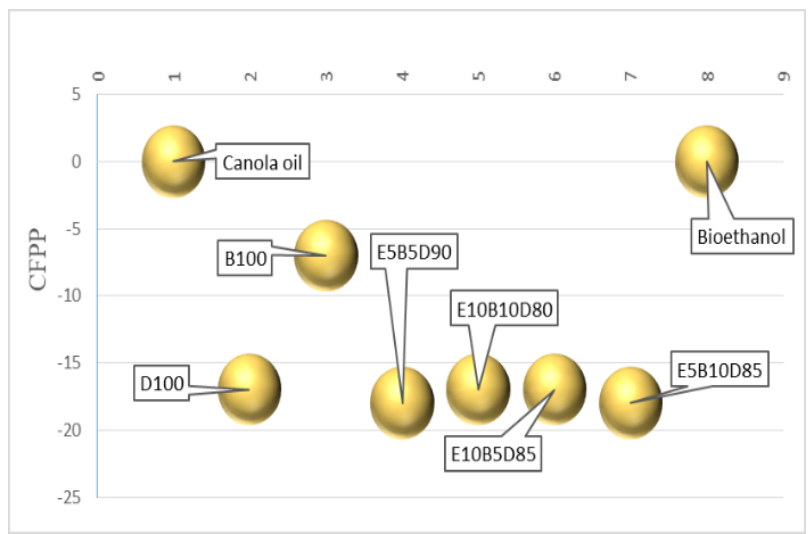

Figure 12. Cold filter plugging point values of the fuels 


\subsection{Copper rod corrosion values of the fuels}

When the copper rod corrosion test values of the fuels were examined, la values were obtained in all fuels and they were not shown in graphics. Copper rod corrosion values were measured according to ASTM D 130 standard.

\section{Conclusions}

In this study, canola oil was transformed into Canola Oil Methyl Esters (Canola Biodiesel) by transesterification method and biodiesel was produced. Biodiesel fuel obtained from canola oil was mixed with diesel fuel with $5 \%$ and $10 \%$ bioethanol addition and by inversion with volumetric proportions, and then fuels in the form of $\mathrm{D}_{100}, \quad \mathrm{~B}_{100}, \quad \mathrm{E}_{5} \mathrm{~B}_{5} \mathrm{D}_{90}, \quad \mathrm{E}_{10} \mathrm{~B}_{10} \mathrm{D}_{80}$, $\mathrm{E}_{10} \mathrm{~B}_{5} \mathrm{D}_{85}$ and $\mathrm{E}_{5} \mathrm{~B}_{10} \mathrm{D}_{85}$ were obtained.

Fuel properties of the obtained mixtures and diesel fuel, density, water content, kinematic viscosity, $\mathrm{pH}$ value, flash point, color specification, calorific value, clouding, pour and freezing point tests, CFPP test and copper rod corrosion tests were performed.

As a result of this study, it was determined that the physical properties of biodiesel produced from canola oil conform to TS EN 14214 standard.

In addition, compared to diesel fuel, due to the fact that the calorific values and other properties of biodiesel and mixtures with bioethanol were close to diesel fuel, it was concluded that biodiesel produced from canola oil could be used as $100 \%$ in diesel engines blending with bioethanol and without any modification on the engine; and it was an alternative fuel to diesel fuel. When all values were investigated, it was seen that $\mathrm{E}_{5} \mathrm{~B}_{5} \mathrm{D}_{90}$ fuel gives the best results.

\section{Acknowledgement}

This study is prepared as a part of Tuğba ŞAHIN's MS Thesis. (Advisor: Dr. Fatih AYDIN)

\section{References}

1. Karagöl, E. T. and Kavaz, İ., 2017, Renewable Energy in the World and Turkey, Seta Foundation, Issue 197, Page7-32.

2. İmrag H. 2006, The Research of the Effect of Bioethanol Usage on Engine Characteristic Values and Exhaust Emissions with Gasoline Engines, MS thesis, The Graduate School of Natural and Applied Science of
Balıkesir University, Balıkesir, pp 15-23.

3. Uyar, M., 2013, "Experimental Investigation of the Effect of $\mathrm{Mno}_{2}$, Dodecanol, Propylene, Glycol Addivites on Biodiesel Fuels Manufactured with the Tans-Esterification Method", MS thesis, The Graduate School of Natural and Applied Science of Frrat University, Elazı ̆̆, pp 1-200.

4. Aydin F. 2014, Effects of Using E-B Diesel Fuel in Single Cylinder Diesel Engine to Engine Performance, Emissions and Lubrication Oil, PhD Thesis, The Graduate School of Natural and Applied Science of Selçuk University, Konya, pp 1-16.

5. İşler, A., 2012, Safflower Oil Ethyl Ester and Life Cycle Assessment, PhD Thesis, The Graduate School of Natural and Applied Science of İstanbul Technical University, İstanbul, pp 1-2.

6. Jitputti, J., Kitiyanan, B., Rangsunvigit, P., Bunyakiat, K., Attanatho, L. and P., Jenvanitpanjakul, 2006, Transesterification of Crude Palm Kernel Oil and Crude Coconut Oil by Different Solid Catalysts, Chemical Engineering Journal, Volume 116, Issue 1, Pages 61-66.

7. Karaosmanoğlu, F., 2007, Fuel Alcohol: Present Status and Future, Biofuels and Biofuels Technologies Symposium, TMMOB Chamber of Chemical Engineers, 12-13 December 2007, pp. 123-132, Ankara.

8. Y1lmaz, 2013, "Bioethanol production analysis with sugar beet, corn and wheat", MS thesis, The Graduate School of Natural and Applied Science of Bahçeşehir University İstanbul, pp 7-24.

9. Bayrakç1, A. G., 2009, An Investigation on Bioethanol Production from Different Biomass Sources, MS Thesis, The Graduate School of Natural and Applied Science of Ege University, İzmir, pp 5-6.

10. Şahin, T., 2018, Effects of Using Biodiesel and Bioethanol Mixture in Single Cylinder Diesel Engine to Engine Performance and Emissions, MS Thesis, The Graduate School of Natural and Applied Science of Necmettin Erbakan University, Konya, pp 3638. 